\title{
Organizational Business Excellence

\section{COMPARATIVE ANALYSIS OF THE KURDISH PROBLEM IN TURKEY AND THE ISSUE OF CHINESE IN MALAYSIA WITHIN THE CONTEXT OF NATION-STATE AND ETHNIC DIFFERENCES}

\author{
Musa Yavuz Alptekin \\ Karadeniz Technical University, Turkey
}

\begin{abstract}
In this study, the ethnic problems which are one of the most significant and perhaps the primary structural difficulties and problems of the nation-state and possible solutions will be suggested. Even if it starts with the general information, the focus of this study would be the subject matter which is known as the Southeastern problem in Turkey, yet it has started to be mentioned as the Kurdish problem in the recent years. This study has the purpose of analyzing the mentioned problem in comparison with the Chinese Problem in Malaysia and determining the advantageous and disadvantageous circumstances in each subsection. Based on those determinations, recommendations will be included regarding which dynamics need to be prioritized in realizing a holistic solution process. The comparison will be conducted in thirteen subsections.
\end{abstract}

Keywords: Turkey, Kurdish Problem, Malaysia, Chinese Problem, Advantages.

\section{INTRODUCTION}

Neither the emergence of the nation-state accidentally took place, nor can it be understood through a superficial approach. The nation-state is a holistic system and sociopolitical application which has emerged as a consequence of a series of social, political, economic, military, religious, philosophical, scientific and technological developments which have been shaped throughout centuries. The fact that it has emerged as a consequence of long-term processes increases its complexity.

The nation-states can be distinguished from their predecessors through certain

\section{ARTICLE INFO}

Article history:

Received: 3 March 2019

Accepted: 18 June 2019

Email Addresses:

m.yavuzalptekin@ktu.edu.tr (Musa YavuzAlptekin)

*Corresponding author characteristics when they are superficially observed from the outside. Perhaps, the first among those distinctions is the borders of a country that are certainly demarcated and protected. The empires as the state structures that precede the nation-states did not have the conception and application of certain country borders and they also did not request such certainty. As a natural necessity of the imperial understanding, it was a more preferred approach to have indefinite borders and to claim that the sovereignty of the empire extended and spread beyond those indefinite borders. The kings, sultans and czars of empires preferred to extend their glory through this vagueness and they hoped it to grow as such.

Another superficial characteristic of the nation-state is its powerful bureaucratic, military and political organization. The nationstate was able to bring together and employ in a certain harmony the functionaries in the 
Alptekin, Musa Y.

number and characteristics that have not been achieved by any of the leaders of the previous states, and it was able to employ them in certain areas of expertise and units of responsibility. The third superficial characteristic of the nation-state is that it has a strong symbolic representation and ceremonial culture. The flag, starboard, banners, official logos, monuments, celebrations, official holidays, parades and commemorations are among the first which come to mind in this context. However, all those are simple reflections of basic characteristics rather than being basic characteristics themselves. Thus, there is a need for a deeper perspective.

In the literature, three basic characteristics of the nation-state are mentioned. Those are respectively sovereignty, citizenship and nationalism. It would not be wrong to say that in the imperial systems that preceded the nation-state, instead of these principles, there were hegemony, subjects and dynasties. If we need to compare even if it is formally, while sovereignty is the legitimate right to rule based on the people, in the last instance hegemony is the right to rule based on the coercive power. Similarly, while the citizenship is an intentional relationship between the particular and the whole, the state and the person, taking the individual as the basis, the subject is more of an inferior-superior relationship that negates the individual will taking the group(s) as the basis. Finally, while nationalism accepts all the people over the land of the state as a particular unity and totality, on the contrary dynasty points out that consent must be provided by the groups, and even by the masses around a particular genealogy of leaders. When compared to the characteristics of the nationstate, there is no doubt that the characteristics of the imperial systems are more top-down and they consider the will of the individual less and they are less honorable. However, the characteristics of the nation-state are not free from problems. Indeed, nationalism of the nation-state comes to the fore as the most problematic and most problem generating characteristic.
The philosophy of the nation-state assumed that differences would come to an end and a new social unity would emerge by the state's perception of the society as united and as a whole through its own political and ideological understanding, perception and targets and by imposing a certain political identity and bestowing citizenship to it. At least, the last two centuries have shown that this assumption had not been an easily materialized, problemfree assumption. The nation-states have failed to reduce the ethnic differences and conflicts into a unity by making them similar despite all nation-building tools and processes. It may be said that the biggest and most general problem of all nation-states was to harmonize ethnic differences under the roof of the same political organization. The difficulty experienced in this regard lies in the fact that ethnic differences greatly vary from one state to the next due to the different understandings, philosophies, approaches and organizational structures of the states as well as different qualitative and quantitative circumstances of various ethnic differences. Opposing advantages and disadvantages might exist from one state to the next within the context of changing criteria. Knowing and determining the mentioned advantages and disadvantages have a great significance in terms of developing a solution and implementing it. This study will attempt to make the mentioned determination comparatively within the context of the Kurds in Turkey and the Chinese in Malaysia.

\section{MATERIALS AND METHODS}

Within the context of the study, thirteen points have been determined which are thought to form the fault lines of ethnic problems in the nation-states. Each one of those thirteen points will be evaluated both in terms of the Kurds in Turkey and the Chinese in Malaysia. Finally, a scoring will be made over five for each point, the most and the least problematic country will be determined and suggestions for a solution will be provided by moving from the successful examples for the solution of the related sub-problems. As it is seen in Table-A, the scoring of the thirteen

Int'1 J. of Org. Bus. Excellence Vol. 2(1): 31 - 46 (2019) 
points will be made over five, and number five (5) will indicate that the problem is at the crisis level, number four (4) will indicate that it has the potential to be evolved into a crisis, number three (3) will indicate that it has reached to a dimension which can't be ignored, number two (2) will indicate that it is about to become unsolvable and number one (1) will indicate that it is solvable. Similarly, while number one points out to a more advantageous and manageable position for the nation-state, number five points out to a highly disadvantageous and crisis situation. In the consequence of scoring out of five for the thirteen criteria, regarding the sum of scoring for each country, the $12-18$ interval will point out to the first stage, the $19-30$ interval to the second, the $31-42$ interval to the third, the 43
- 54 interval to the fourth and finally the 55 60 interval to the fifth stage. Thus, while the 12 - 18 interval points out to the most advantageous and relatively to the best and most manageable situation, the 55- 60 interval will point out to the crisis situation which is the most disadvantageous one. The gaps between every two groups represent the relatively manageable ones and the distance to the crisis situation. As it is clearly seen, this analysis method will be able to work as a scale and it will be able to be implemented to the other examples. Indeed, the preparation is ongoing where the will be implementation of this scale to about ten different ethnic groups in the developed and developing countries of the world and make a comparative analysis within the context of the Kurdish problem.

Table 1. Table Display of the Units of Scale

\begin{tabular}{lccccc}
\hline Numbers & $\mathbf{1}$ & $\mathbf{2}$ & $\mathbf{3}$ & $\mathbf{4}$ & $\mathbf{5}$ \\
\hline Description & $\begin{array}{c}\text { Advantageous, } \\
\text { Manageable }\end{array}$ & $\begin{array}{c}\text { Getting Out } \\
\text { of Control }\end{array}$ & $\begin{array}{c}\text { Has the } \\
\text { Potential to } \\
\text { Grow }\end{array}$ & $\begin{array}{c}\text { Close to } \\
\text { the Crisis } \\
\text { Level }\end{array}$ & $\begin{array}{c}\text { Disadvantageous, } \\
\text { Crisis Level }\end{array}$ \\
\hline
\end{tabular}

\section{Historical Background and Homeland}

Regarding the ethnic differences that the nation-states contain, the quality and quantity of the problems that they encounter are closely related to their historical background and where their homeland is over the lands where those ethnic differences exist. The ethnic group or groups in a country might be insistent on their ethnic group and ethnic identity claims as much as they think of themselves as ancient in those lands. The older ethnic group makes more insistent ethnic claims than the newer one. The issue of homeland is the most extreme case of this matter. If an ethnic group considers its country as its homeland, the problem may get bigger in this case. Thus, there is no doubt that an ethnic group which considers itself living in its own homeland would put its nation-state in a more difficult situation when compared to others.

The locations of the ethnic groups in their lands correspond to two different cases except the homeland. One of them is immigration, and the other one is the case of historical existence. The first one is called immigrant societies, and the second one is called historical nationalities. The first one has a low potential of creating ethnic problems. However, sometimes the second one may have a potential of creating ethnic problems as much as the local and autochthonous peoples claiming to live in their homeland. Thus, it is possible to divide communities into four, based on their level of antiquity where they live ${ }^{1}$. In terms of their antiquity from the oldest ones to the newest, those are respectively the local peoples, autochthone peoples, historical nationalities and immigrant peoples. Similarly, each one of those four groups may become a "nation" as the primary element, which has established a nation-state where they are located, may become a "minority", "autonomous community" and even a "federal unit" within a nation-state whose identity and

\footnotetext{
${ }^{1}$ For a more detailed interpretation in this matter, please see: M. Yavuz Alptekin, "Seven Stages of Spread of Kurdish Population in Anatolia throughout History and Its Effects on the Current Kurdish Issue in Turkey" (in press).
} 
Alptekin, Musa Y.

certain rights are recognized; and finally may become "citizens" who are addressed in the individual level although they demand certain group rights by claiming that they are different. In the case of comparing the Kurds in Turkey and the Chinese in Malaysia in terms of their historical backgrounds and their homelands, two separate cases emerge which are somewhat similar in same aspects, and yet very different in some other. It is commonly accepted information that the homeland of the Kurds in Turkey is located in Iran (McDowall, 2004; Natali, 2009). In this case, it may be argued that the Kurds in Turkey are not a local people and they are not an autochthone people either. As it is, it might be thought that the ethnic problems and demands that the Kurds in Turkey would put forward would not be very big. However, despite the fact that the historical information is in this direction, majority of the Kurdish population in Turkey know that they live in their own homeland; namely they assume themselves as the locals of these lands. This last situation creates a mass imagination and a de facto situation that complicates the ethnic problem that the historical information eases. In Malaysia, the situation is relatively easier in this regard. Because the contemporary Chinese population in Malaysia is composed of those who migrated to the country in the last two centuries, except the Baba Chinese in limited numbers who migrated to Malaysia in the $16^{\text {th }}$ century. It may be said that almost all Chinese in Malaysia are in the position of immigrants and it is not expected from them to have high ethnic demands. Actually, the Chinese community in Malaysia is composed of the children of the immigrant worker families who were brought to the country in the period under the British colonial administration mostly to be employed in the tin mines. It may be certainly said that these people are an immigrant community in this country. However, it may also be claimed that they are historical nationality when their three hundred year stay in the country is considered. In conclusion, the Chinese do not set an example of an ethnic group that makes a lot of ethnic demands in Malaysia. Indeed, it is indicated in the constitution and the laws that positive discrimination would be provided for the Malays, especially in certain areas such as employment and education. Despite the fact that the Chinese are in a secondary position, they do not oppose this situation much possibly due to the immigration psychology. Thus, it may be claimed that Turkey is in a more disadvantaged position than Malaysia in terms of the historical background and homeland situation of the ethnic group in the country where it is located.

Table 2. Quantitative Scoring and Comparison in Terms of Historical Background and

Homeland

\begin{tabular}{lcc}
\hline $\begin{array}{l}\text { Country and } \\
\text { Ethnic Groups }\end{array}$ & $\begin{array}{l}\text { The Kurds } \\
\text { in Turkey }\end{array}$ & $\begin{array}{l}\text { The Chinese } \\
\text { in Malaysia }\end{array}$ \\
\hline Scoring & 4 & 2 \\
\hline
\end{tabular}

In terms of the first criterion, it is clear that Malaysia is in a much better situation when compared to Turkey. However, Turkey is not in the worst position in this regard. When the issue is taken from this perspective, it may be claimed that the worst examples, namely the examples which may be scored with number 5 , are South Sudan before the independence and the Basque Country before the autonomy. Both examples represent the peoples who live in their own homelands both in terms of historical information and of social imagination. They have obtained independence and autonomy through the congruity of other static factors and the dynamic world politics. Contrarily it may be said that the best examples, namely the manageable examples which may be scored with number 1 , are the Turkish immigrants in Germany or in France. ${ }^{2}$

\footnotetext{
${ }^{2}$ From this perspective, for instance the Algerians in France and the Indians in England may not be compared with the Turks in Europe. There was no colonial relationship between Turkey and the European countries in the past. However, in the first group, this relationship existed and the immigrants of the colonized societies might claim more rights for themselves when compared to the others. The social imagination is in this direction and from this perspective; it may be separated carefully and analyzed separately.
} 


\section{Demographic Size (Ratio)}

It is clear that big ethnic differences in terms of demography may create much bigger problems for the nation-states where they are located. It may be said that the ethnic groups with bigger percentage ratios would have bigger demands and those with smaller ratios would make smaller and limited demands. In this regard, it is possible to divide the ethnic groups in nation-states in three groups such as the big-sized ethnic groups creating big problems, mid-sized ethnic groups creating demands in the medium level, and the smallsized ethnic groups making smaller demands.

When the Kurds in Turkey and the Chinese in Malaysia are evaluated in terms of their population ratios, still two separate situations emerge. When the issue is taken in this regard, it may be said that the Kurds in Turkey have a ratio between 13 and 18 percent of the general population in Turkey (Yeğen, Uğraş \& Mehmet Ali, 2016). Although there are many speculations about this matter, the results obtained by trusted polling organizations fall between these percentage margins. While the Turkish nationalists usually provide this ratio between 6 and 12 percent, the Kurdish nationalists usually provide this ratio between 20 and 30 percent. However, none of those numbers are based on trusted studies.

On the other hand, the Chinese in Malaysia comprise 26 percent of the country's total population (Abdullah \& Pedersen, 2009). There are not many speculations regarding the percentage of the Chinese in Malaysia. Indeed these numbers are the ones that are provided by the Malaysian state institutions regarding statistics and demographics. When the issue is taken from this perspective, it may be said that Turkey is more advantageous than Malaysia. Because there is at least a substantial 8 percent difference between the Chinese population in the total population of Malaysia and the Kurdish population in the total population of Turkey.

Table 2. Quantitative Scoring and Comparison in Terms of Demographic Size (Ratio)

\begin{tabular}{lcc}
\hline $\begin{array}{l}\text { Country and } \\
\text { Ethnic Groups }\end{array}$ & $\begin{array}{l}\text { The Kurds } \\
\text { in Turkey }\end{array}$ & $\begin{array}{l}\text { The Chinese } \\
\text { in Malaysia }\end{array}$ \\
\hline Scoring & 3 & 4 \\
\hline
\end{tabular}

In terms of demographic size, Malaysia is in a more disadvantaged position than Turkey. However, in this regard, Malaysia is not one of the countries in the most difficult situation. In this regard, it may be, for instance, claimed that Iran is in a more difficult situation. Indeed, the Azeri Turks in this country have a population which is around 30 percent of the total population of the country. However, the Shi'ite belief may function in a way that it removes ethnic differentiation by religious and sectarian unity to a large extent (See for further information at Sarikaya, 2008). Thus, Iran does not experience problems with the Shi'ite Azarees which constitute 30 percent of the country's population as much as the problems that Iran experiences with the Sunni Kurds which constitute 15 percent of the country's population.

\section{Regional Demographic Intensity}

It may be easily said that the ethnic differences intensified in a certain section of the nationstate may create much bigger problems for the countries where they are located. When the issue is taken from this perspective, the ethnic groups may be divided into three groups in terms of their intensity in a certain region of the country such as intensive, less intensive and sparse. It is possible determine the intense existence of the ethnic groups in terms of their percentage of population where they are located by their existence at least 75 percent, the less intense existence by around 50 percent and the sparse existence by 25 percent at most. While the intense ones are those having the potential of making the most demands, the sparse ones may be categorized as those making the least demands or none at all. However, quantity is not always the absolute determinant, and the primacy and significance of the holistic approaches peculiar to different examples will always be accepted. 
Alptekin, Musa Y.

The cities where the Kurds in Turkey have traditionally lived are located in the eastern and southeastern regions of Turkey. However, it needs to be indicated that villages and rural areas, not cities, are the traditional living spaces of the Kurds as a natural consequence of the nomadic lifestyle. Indeed, the Kurdish population has a percentage of more than 50 percent in the eastern and southeastern Anatolian regions with the highest rural characteristics. The population intensity in these two regions worth mentioning; although in any of the other five regions does the Kurdish population density exceed 20 percent. In eleven cities in these two regions, the ratio of the Kurdish population is higher than 50 percent in varying degrees. However, the fact that these eleven cities are located inland and that they lack aerial and naval corridors constitute a realpolitik situation.

In Malaysia, the Chinese who have a ratio of 26 percent in the total population are mostly located in the cities rather than rural areas. As the Chinese are a community which is located mostly in the cities, they have gained certain social and economic characteristics accordingly. For instance, their birth rates are low; however their level of education is high.
Besides other factors, partially due to these two factors their economic productivity is higher and their managerial and ownership positions in the economy are larger and extensive when compared to the Malays.

The Chinese population in Malaysia has an intense ratio in the cities, especially in the bigger cities. There are roughly 40 cities in Malaysia and as it is seen in Table- $A$, the Malays constituted half of the city's population in only one (Johor-Bahru) of the eight cities having a population more than 80 thousand people in 1970, and in the remaining seven cities the Chinese constituted more than half of the population. Although this situation has changed greatly today due to the increase of the birth rates and urbanization of the Malays, the dominance of the Chinese population in Penang and Ipoh still continues today. Besides, the fact that part of the Penang Autonomous Administration is formed by a separate island brings into minds the "Salt Water Theory". However, the drawing of the boundaries of the autonomous region, perhaps purposefully, in a way that a portion of the region resides in the Malay Peninsula makes this situation greatly easier.

Table 3. Distribution of the Ethnic Groups in the 8 Biggest Cities in Malaysia in 1970.

\begin{tabular}{lrcccc}
\hline \multicolumn{1}{c}{ Cities } & Population & $\begin{array}{c}\text { Malaysia } \\
\%\end{array}$ & $\begin{array}{c}\text { Chinese } \\
\%\end{array}$ & $\begin{array}{c}\text { Indians } \\
\%\end{array}$ & $\begin{array}{c}\text { Others } \\
\%\end{array}$ \\
\hline Kuala Lumpur & 452.000 & 25 & 55 & 19 & 1 \\
\hline Penang (G.T.) & 269.000 & 14 & 72 & 13 & 1 \\
\hline Ipoh & 248.000 & 13 & 72 & 14 & 1 \\
\hline Johore Bahru & 136.000 & 50 & 39 & 8 & 3 \\
\hline Klang & 114.000 & 21 & 58 & 20 & 1 \\
\hline Petaling Jaya & 93.000 & 20 & 63 & 14 & 3 \\
\hline Malacca & 87.000 & 15 & 75 & 7 & 3 \\
\hline Seremban & 81.000 & 21 & 59 & 19 & 1 \\
\hline
\end{tabular}

When the ethnic groups in Turkey and Malaysia are compared in terms of the areas where they concentrate, it will be realized that when compared to the Chinese, the Kurds intensely live together in certain regions and cities more than the Chinese do. Indeed, while the Chinese comprise majority in Malaysia only in Penang which is a small state, the Kurds in
Turkey comprise majority in two regions one of which is the second largest region in Turkey. Especially the fact that the Kurdish population ratio in the eastern and southeastern Anatolia is higher than 50 and 60 percent respectively may be properly accepted as intensification. However, no such thing is possible for the Chinese in Malaysia outside of Penang which is

Int'1 J. of Org. Bus. Excellence Vol. 2(1): 31 - 46 (2019) 
one of the smallest regions. When the issue is considered comparatively in all aspects, it may be said that the Chinese in Malaysia have been spread sparsely when compared to the Kurds in Turkey and as it is seen in Table-3, Turkey is in a more disadvantageous position as a nation-state in terms of this criterion.

Table 4. Quantitative Scoring and Comparison in Terms of Regional Demographic

\begin{tabular}{lcc}
\hline $\begin{array}{l}\text { Intensity } \\
\text { Country and } \\
\text { Ethnic Groups }\end{array}$ & $\begin{array}{l}\text { The Kurds } \\
\text { in Turkey }\end{array}$ & $\begin{array}{c}\text { The Chinese } \\
\text { in Malaysia }\end{array}$ \\
\hline Scoring & 4 & 3 \\
\hline
\end{tabular}

However, Turkey is not among the countries in the worst situation in terms of this criterion. It is clear that the nation-states that are in the most difficult situation in terms of regional intensity are those that are within the group of separate islands, peninsulas or archipelagos which reminds us the Salt Water Theory of ethnic differences. The lack of both regions where the Kurds in Turkey lived intensely of aerial and naval corridors opening to the rest of the world creates an impact which closes the mentioned intensity to outside manipulation to a great extent. And this makes it possible for Turkey to make this ethnic problem more manageable at least in terms of this criterion.

\section{Strategic Spread of Population}

The spread of the different ethnic group within the nation-state to strategic regions, cities and points will make it difficult for that nation-state to manage that ethnic difference. Because at least, the relevant ethnic group may manipulate itself with the self-confidence provided by the demographic dominance over the strategic regions, cities and points and it may also be influenced from abroad in this regard. The strategic spread of an ethnic group may generally be in three ways. The first one is the concentration of the relevant ethnic group at the points such as straits, portal cities, coastal cities, capitals and big cities which have strategic significance for a country. This situation certainly exists in terms of the
Chinese in Malaysia. The second one is the concentration of the relevant ethnic group in the regions and cities that are characterized by high potential such as economically powerful or rich underground resources. Such a situation exists in terms of the Basques and Catalans in Spain. The third one is the location of the different ethnic group in the coastal region or the region which is adjacent to the neighboring state which is the enemy of the country.

As it is mentioned earlier, the Chinese in Malaysia are subject to one of the three possible strategic spreads of an ethnic group. The Chinese have a large and high representation the cities with powerful economies, primarily in the capital city. And this is a great source of concern for Malaysia. In order to eliminate this situation, Malaysia determined "reserved" regions particularly in the capital city, and safeguarded this policy with the laws, particularly with the constitution. Similarly, there are cases where the Malays are subjected to positive discrimination in terms of security forces and certain professions against the Chinese and Indians. Lastly, the population increase of the Malays and their immigration into the cities are encouraged.

Table 5. Quantitative Scoring and Comparison in terms of Strategic Spread of the Population

\begin{tabular}{lcc}
$\begin{array}{l}\text { Country and } \\
\text { Ethnic Groups }\end{array}$ & $\begin{array}{l}\text { The Kurds } \\
\text { in Turkey }\end{array}$ & $\begin{array}{l}\text { The Chinese } \\
\text { in Malaysia }\end{array}$ \\
\hline Scoring & 3 & 4
\end{tabular}

In Turkey, the Kurds do not have a distinct strategic spread which is similar to the Chinese in Malaysia. In this regard, perhaps it may be pointed out that the Kurds in Turkey share two sides of the same border with the Kurdish communities in the neighboring countries. Such a situation might have pointed out to a strategic situation if the other side of the border had been economically more advanced. However, as the other side of the border is less advanced than Turkey, it is not possible to mention a significant strategic situation. Thus, when the issue is taken in terms of this criterion, it may be said that Malaysia is in a

Int'1 J. of Org. Bus. Excellence Vol. 2(1): 31 - 46 (2019) 
Alptekin, Musa Y.

more difficultly manageable and more disadvantageous situation than Turkey.

However, it also needs to be indicated that Malaysia is not in the worst position in terms of this criterion. In this regard, Malaysia has experienced two big events, first being in the Second World War and the second being in the year of 1969 and it was able to overcome both situations by maintaining the unity of the country. In the Malaysian case, if the Chinese had spread into two regions, the relevant most difficult situation might have taken place. The first possibility that comes to mind is the intensification of the Chinese around the Singaporean border. In such case, unification with Singapore might be in the agenda because Singapore was also developed. The second possible situation is the intensification of the Chinese around one or both autonomous regions named Sabah and/or Sarawak in the Borneo Island. In such case, separation might have been placed in the agenda. However, the Chinese did not even actually open the issue of separation up for discussion until today at the national level.

\section{International Spread of the Population}

One of the difficult situations for the nationstates is the case where one of the ethnic groups in the country has similar counterparts in the neighboring countries. Mostly such groups exist in both sides of the border between the nation-states spreading in different ratios in each country. In some cases, the number of states is two, and sometimes it may be three and even four. For instance, while the Basques are spread in two countries between Spain and France, the Baluchis are spread in three countries between Iran, Afghanistan and Pakistan. Lastly, the Kurds are spread in four countries between Iran, Iraq, Turkey and Syria. While the limitation of an ethnic group only within the country where it is located makes that ethnic group and the problems related to it more manageable, its spread into more than one country may make that problem unmanageable to the extent of the number of countries. Thus, one of the reasons of the increase and ramification of the problems of the Kurds in Turkey is the Kurdish communities in other three countries. This situation causes a domestic problem of Turkey to turn into a non-Turkish and international problem. And this causes the problem to become relatively more unmanageable.

The Chinese exist as a separate state only in Singapore despite the fact that the Chinese have a few states in the Far East and they exist in some states as immigrant minorities. As it is seen in the Salt Water Theory, the naval distance in such cases that comes in between the ethnic groups prevent them from unifying by playing an exactly contrary role. A phenomenon that may be called as land extension causes a similar effect in unifications which is similar to the one explained by the Salt Water Theory in separations. Thus, for a problem related to an ethnic group located in a nation-state to gain an international dimension, the related ethnic group must have a land extension to the neighboring state. Namely, on the other side of the land borders, the same ethnic group needs to live in certain intensity. This case is highly valid for the Kurds who are among the two examples that are examined here, however it is largely invalid for the Chinese. Although the Chinese live in Singapore in certain intensity, two matters worth paying attention. First matter is the lack of land extension. Second matter is that the Malay region which is close to Singapore is not a region where the Chinese intensely live.

Table 6. Quantitative Scoring and Comparison in Terms of International Spread of the

\begin{tabular}{lcc} 
Population & & \\
\hline $\begin{array}{l}\text { Country and } \\
\text { Ethnic Groups }\end{array}$ & $\begin{array}{c}\text { The Kurds } \\
\text { in Turkey }\end{array}$ & $\begin{array}{c}\text { The Chinese } \\
\text { in Malaysia }\end{array}$ \\
\hline Scoring & 4 & 2 \\
\hline
\end{tabular}

As the situation of the Kurds in Iran, Iraq and Syria is not better than the situation of the Kurds in Turkey, the Kurds in Turkey do not have an open demand so as to unify with any one of those countries. Thus the situation is not perceived at the crisis level. However, the PKK's finding of human resources, material resources and refuge greatly from those three

Int'1 J. of Org. Bus. Excellence Vol. 2(1): 31 - 46 (2019) 
countries makes the situation highly problematic. On the other hand, as it is mentioned earlier, the Chinese problem in Malaysia has a largely lower potential to gain an international dimension when compared to the Kurds due to the following reasons: first, the Chinese in Malaysia are an immigrant community, second, the land extension principle is interrupted, namely Singapore, which is the closest Chinese state, is separated from the Malaysian peninsula by a channel, and third, the region of Malaysia which is close to Singapore is one of the regions where the Chinese live in the sparsest way.

\section{Social Structure and Lifestyle}

Table 7. Quantitative Scoring and Comparison in Terms of Social Structure and Lifestyle

\begin{tabular}{lcc}
\hline $\begin{array}{l}\text { Country and } \\
\text { Ethnic Groups }\end{array}$ & $\begin{array}{l}\text { The Kurds } \\
\text { in Turkey }\end{array}$ & $\begin{array}{l}\text { The Chinese } \\
\text { in Malaysia }\end{array}$ \\
\hline Scoring & 4 & 2 \\
\hline
\end{tabular}

The management of the ethnic groups whose social structures and lifestyles have distinctively become different may be more problematic for the nation-states. In this regard, Turkey appears to me more disadvantageous than Malaysia. Indeed, the Kurds in Turkey are distanced and stay away from city life in regards to settled lifestyle due to their lifestyles and traditional habits. To put a finer point on it, the social structures of the Kurds coming from the feudal times, their large familial structures of clans, tribes and family lines based on blood ties, and their lifestyles with distinctive rural characteristics compatible with these structures may create certain problems in Turkey where majority of the population is urbanized. Especially in the urban environments, the Kurds are intertwined with many problematic situations. This situation negatively affects the state's and other social segments' communication, social dialogue and sustainable positive relations with the Kurds. However, the vast majority of the Chinese in Malaysia live in the cities and when compared to the Malays, they have a high social culture. It may even be claimed that in terms of lifestyles, the Chinese create less problems than the rural Malay population.

Despite everything, it may be said that Turkey is not in the worst situation in terms of this criterion. Indeed, it must be certainly indicated that the Kurds in Turkey are in a better situation in terms of type of social organization and lifestyles when they are compared to the Kurdish groups in the neighboring countries.

\section{Intermarriages between Ethnic Groups}

In a multiethnic society, one criterion of social integration is intermarriages between different ethnic groups. It may be said that the idea that in the countries where such marriages are relatively higher, the problems between the ethnic groups would be or must have been solved easily would have a large support in the public opinion. Thus, it may be anticipated that the nation-states where intermarriages between the ethnic groups are relatively widespread would manage the ethnic problems easily. In Turkey, it may be argued that the intermarriages between the Kurds and Turks are relatively higher. Indeed, according to a study made in 2002 by Gündüz-Hoşgör and Smits, 1.7 of every 100 marriages that Turks perform is with the Kurds, and 9.8 of every 100 marriages that Kurds perform are with the Turks. The data of the same study indicate that the average ratio has increased over the years. Accordingly, the ratio of Turkish-Kurdish marriages, which was 1.6 percent before 1976, has increased to 2.3 percent between the years of 1976 and 1988 and to 3.0 percent between the years of 1989 and 1998 (Gündüz-Hoşgör \& Smits, 2002). If we have a look at the study made by KONDA in 2006, this increase trend has been continuing. Because according to this study, the ratio of the Turkish-Kurdish marriages was 3.7 percent for the related year (KONDA, 2006).

In Malaysia, the social relations between the two ethnic groups are more distanced due to the differences in religion and it may be predicted that the Malay and Chinese marriages in Malaysia are more limited due to

Int'1 J. of Org. Bus. Excellence Vol. 2(1): 31 - 46 (2019) 
Alptekin, Musa Y.

the holy context of the marriage institution. Indeed, J.

Edmonds indicates that religion in general and Islam in particular serves as a barrier that does not allow marriages between the two ethnic groups. There are many studies that indicate the same observation (Edmonds, 1968; Hirchman, 1985).

Table 8. Quantitative Scoring and Comparison in Terms of Intermarriages between Ethnic

Groups

\begin{tabular}{lcc}
\hline $\begin{array}{l}\text { Country and } \\
\text { Ethnic Groups }\end{array}$ & $\begin{array}{c}\text { The Kurds } \\
\text { in Turkey }\end{array}$ & $\begin{array}{l}\text { The Chinese } \\
\text { in Malaysia }\end{array}$ \\
\hline Scoring & 2 & 5 \\
\hline
\end{tabular}

This matter points out to the most difficult situation of Malaysia in terms of managing the relations between ethnic groups. In Turkey, although there is no ideal situation, it is obvious that there is a manageable situation. At least, the problem of Turkey is not the insufficient amount of marriages between the Turks and the Kurds, and a negative perspective regarding this issue is also fairly limited. It is known that through urbanization, this negative perspective turns into a positive one and the related ratios are higher in the cities.

\section{Social Status and Socio-Economic Developmental Level}

As economic development creates a social status alongside itself over time, under this subheading both topics are analyzed together. It may be said that it would be more difficult to manage ethnic groups with lower social status and economic developmental level. Because it is inevitable that the communities, which lack social status and high economic levels, would associate this situation with their ethnic identities and feel excluded. It may be anticipated that the members of such an ethnic group would create various problems not in a planned way, but in an improvised way. The economically backward situation of the dominant ethnic group for a nation-state is a more manageable situation than the poverty of a minority ethnic group. Because the dominant ethnic group may be contented with psychological satisfaction, and the minority ethnic group may be contented with economic satisfaction. However, the reverse situation is not valid. When the matter is perceived from this perspective, the situation of the Kurds in Turkey and the situation of the Chinese in Malaysia indicate completely dissimilar examples.

The economic condition of the Chinese in Malaysia is many times better than that of the Malays'. The social statuses of the Chinese, who mainly live in the cities, are dominant in the industries and occupy managerial and ownership positions in the commercial establishments, are much higher than those of the Malays'. Although, before the governmental bodies, the Malays are more respectable, there is no doubt that socially the Chinese have a higher prestige. In terms of modern economic development, the situation of the Malays against the Chinese is incomparable. Although this situation is attempted to be corrected within the last decades in a planned way, it may not be said that it has been very successful. The infamous book of Mahathir Mohamad (1981) titled The Malay Dilemma exactly problematizes this matter. For instance, according to the 1970 data, the ownership position of the Malays in the economy was 1.9 percent, of the Chinese, Indian and non-Malay citizens was 37.4 percent, and of the foreigners was 60.7 percent (Jesudason, 1989; Gullick, 1987).

Similarly, as of 1958, of the total national income, the Malays got 30 percent, the Chinese got 54 percent and the Indians got 13 percent (Rabushka, 1973). In 1975, while the ownership position of the Malays in the commercial establishments rose up to 8 percent, the foreigners' position went down to 55 percent (Young, Bussink, \& Hasan, 1980). As it is seen here, the remaining 37 percent of the companies were under the ownership of nonMalay citizens of Malaysia, namely the Chinese and the Indians. In the years of 1969 and 1999, while the poverty rates of the Malays and the Chinese in Malaysia were respectively 65 percent and 10.3 percent, it was determined as 26 percent and 1.6 percent for the Chinese

Int'1 J. of Org. Bus. Excellence Vol. 2(1): 31 - 46 (2019) 
(Nair, 2007: 119). Over time, although the situation of the Malays against the Chinese has relatively improved due to positive discrimination of the governments, it is far from competing with them (Alptekin, 2015). However, the economic underdevelopment of the Malays is an assessment in the modern sense, and it does not have such a meaning in the cultural world of the Malays. The Malays are mostly contented with their situation. This situation is a matter of concern mostly for the politicians. Indeed, a contrary situation might have dragged the Malay nation-state into a great deadlock.

In Turkey, the situation is somewhat the opposite with a difference of degree. The level of economic welfare of the Kurds is backward when compared to other communities, and their social development levels and social statuses are relatively lower. Roughly, the urban communities are in a better position in terms of level of social development when compared to the rural communities, and the settled communities in the rural areas when compared to the nomadic communities. When the issue is analyzed in detail, within each lifestyle, education, level of income and socialization level come forward as the factors that greatly determine the level of social development of the communities. Although the Kurds in Turkey are in a better position in terms of all of these criteria when compared to the Kurdish communities in the neighboring countries, they fall behind in comparisons inside Turkey. One of the most difficult situations for a nation-state is to satisfy an ethnic group whose socio-economic situation is backward and protect them from cases that are open to manipulation. Such communities generally become subject matters of manipulations both domestically and internationally.

Table 9. Quantitative Scoring and Comparison in Terms of Social Prestige and Level of SocioEconomic Development

\begin{tabular}{lcc}
$\begin{array}{l}\text { Country and } \\
\text { Ethnic Groups }\end{array}$ & $\begin{array}{l}\text { The Kurds } \\
\text { in Turkey }\end{array}$ & $\begin{array}{l}\text { The Chinese } \\
\text { in Malaysia }\end{array}$ \\
\hline Scoring & 3 & 1
\end{tabular}

As it is seen, Malaysia is one of the best countries in terms of development of social and economic level of an ethnic group. The Chinese may give up their demands in many other areas of life due to their socio-economic development. Among those, the political demands are the most important. Despite the fact that the Chinese comprise a quarter of the country's population, they do not deem it quite necessary to make political demands. However, the situation of the Kurds in Turkey is quite the contrary. The Kurds are both backward in terms of the regions where they live and they have a lower socio-economic developmental level as an ethnic group. It is certain that these conditions increase manipulation alongside themselves. It is a wellknown matter that the violent organizations greatly abuse this situation.

\section{Religious Homogeneity and Religious Rights}

One of the determinants that make the ethnic groups more manageable for the nationstates is the matter of religious homogeneity. It may be said that in this regard, Turkey is almost ideally well. Both the Turks and the Kurds adhere to Islam, and besides, they both adhere to the Sunni interpretation of Islam. Although there is a sectarian difference between the two, it is not seen as very significant. However, the fact that some of the Kurds adhere to the Alawite belief changes the situation a little bit. In this case, the overlapping of both ethnic and religious differences may create problems. Indeed, it is believed that the ratio of the Alawite militants in the PKK is higher than the ratio of the Alawite Kurds within the Kurds. And in terms of religious rights, the Kurds request that the prayer leaders of the mosques who adhere to the Shafi'i sect knowing Kurdish in the rural areas of the eastern and southeastern regions where the Kurdish population is especially dense. However, ideally it may not be said that this request has been fully met. These matters constitute relatively small problems.

In Malaysia, the religious distance between the two communities is far more distant.

Int'1 J. of Org. Bus. Excellence Vol. 2(1): 31 - 46 (2019) 
Alptekin, Musa Y.

Majority of the Chinese are Buddhists, Confucians and Taoists respectively (Abdullah $\&$ Pedersen, 2009). All of these religions are theologically and culturally distant from Islam. Indeed, this religious distance is clearly visible between the Muslim Malays and the Chinese in every aspect of life.

Table 10. Quantitative Scoring and Comparison in Terms of Religious Homogeneity and Religious Rights

\begin{tabular}{lcc}
\hline $\begin{array}{l}\text { Country and } \\
\text { Ethnic Groups }\end{array}$ & $\begin{array}{l}\text { The Kurds } \\
\text { in Turkey }\end{array}$ & $\begin{array}{l}\text { The Chinese } \\
\text { in Malaysia }\end{array}$ \\
\hline Scoring & 2 & 4
\end{tabular}

Although the differences of beliefs of the Chinese in Malaysia are great and salient, there is at least an official and formal mutual tolerance in this regard. On the other hand, the turning of this matter into a reason for conflict and later into conflict is beside the point.

\section{Linguistic Differences and Native Language Right}

An ethnic group's having a different native language and making demands in this regard are one of the most difficult matters regarding the nation-states. The most important demand regarding the language is the demand for education in the native language. The rights regarding publications, media and the ability to use the native language in the courts follow this. It may be said that both in Malaysia and Turkey, there are important problems regarding this matter. Although the official language in Malaysia is Malay, the de facto second official language is English. In all of the public institutions, the back side or the bottom section of all the forms and documents are spared for English. However, no such official or nonofficial opportunity exists for Chinese. While education in any language other than Malay is banned in state schools, the Chinese may have education in Chinese in their own private schools. As most Chinese live in the cities, there is almost little to no Chinese who do not have access to private schools in this regard. However, the Malaysian State has banned the languages at the university level other than Malay and English. Thus, the
Chinese send their kids for university education to America, Australia or China. No problems are encountered regarding publications and media in Chinese.

Turkey is engaged in more problems than Malaysia regarding this matter. Although Kurdish was allowed in the education of private elementary schools and the related graduate programs of the universities, two important points need to be considered. First, the percentage of the Kurds who live in the rural areas and can't afford a private school is much higher when compared to the Chinese in Malaysia. Second, perceiving the graduate educational facilities in Kurdish which is seen as necessary by a limited number of people as a basic educational right and its satisfaction of the masses may not be expected. Despite the fact that the Kurdish press exists (although in limited numbers), the broadcasting in Kurdish may only be made through the state television channels.

Table 11. Quantitative Scoring and Comparison in Terms of Linguistic Differences and Native

Language Right

\begin{tabular}{lcc}
\hline $\begin{array}{l}\text { Country and } \\
\text { Ethnic Groups }\end{array}$ & $\begin{array}{c}\text { The Kurds } \\
\text { in Turkey }\end{array}$ & $\begin{array}{c}\text { The } \\
\text { Chinese in } \\
\text { Malaysia }\end{array}$ \\
\hline Scoring & 4 & 3
\end{tabular}

Until recently, it would be claimed that Turkey was among the most problematic countries in this regard. However, it may be said that the situation has improved somewhat through partial improvements in the last decade.

\section{Cultural and Educational Situation and the Related Rights}

Being different than the right of native language, Turkey is far ahead of Malaysia regarding cultural and educational situation and rights. The first among the two reasons that create this difference is that the Chinese mostly live in the cities and secondly, their economic situation is much better when compared to that of the Kurds'. As it is seen in Table-C, the literacy and educational level of

Int'1 J. of Org. Bus. Excellence Vol. 2(1): 31 - 46 (2019) 
the Kurds in Turkey is much backward that those of the Turks'.

Table 12. Educational Levels According to the Turkish and Kurdish Populations (KONDA, 2010).

\begin{tabular}{|l|c|c|c|c|c|c|}
\hline & Illiterate & Uncert. Lit. & Primary Sc. & Secondary & $\begin{array}{l}\text { High } \\
\text { School }\end{array}$ & $\begin{array}{l}\text { Univ. \& } \\
\text { B. }\end{array}$ \\
\hline Turks & 4 & 2 & 38 & 15 & 27 & 13 \\
\hline Kurds & 17 & 9 & 33 & 15 & 18 & 7 \\
\hline
\end{tabular}

In Malaysia, quite contrarily, the educational and cultural levels of the Chinese are much higher than those of the Malays'. This situation allows the Chinese to voice their problems regarding their ethnic identity in a much more civilized way. It may be clearly stated that due to the fact that the Chinese are mostly urban dwelling, educated, accomplished and economically satisfied people, they don't feel the need to resort to any kind of organized or individual violence.

Table 13. Quantitative Scoring and Comparison in Terms of Cultural and Educational Situation and the Related Rights

\begin{tabular}{lcc}
\hline $\begin{array}{l}\text { Country and } \\
\text { Ethnic Groups }\end{array}$ & $\begin{array}{c}\text { The Kurds } \\
\text { in Turkey }\end{array}$ & $\begin{array}{c}\text { The Chinese } \\
\text { in Malaysia }\end{array}$ \\
\hline Scoring & 4 & 1 \\
\hline
\end{tabular}

It may be claimed that the cultural backwardness of the Kurdish people in Turkey and their inability to raise their level of education at least as much as that of the Turks' causes certain disharmonies in social life and the PKK feeds from this social basis.

\section{Political Organization and Political Rights}

Although the political organization and political rights don't directly solve actual problems of the ethnic communities, they are one of the areas of improvement and social rights that the ethnic groups value the most from the perspective of creating psychological satisfaction. However, for the nation-states, delivering those rights appears to be dangerous as well. Because the nation-state thinks that the ethnic groups which have achieved those rights would gradually lead to the separation of the country. Thus, it may be said that the matters of political rights and political organization are an area where the nation-states have difficulties in managing ethnic problems.

The existence of a Chinese ethnic group in Malaysia is officially and socially recognized in an actual way. In terms of organization, the Chinese may establish Chinese parties to represent themselves. Similarly, autonomy was given to Penang where the Chinese live intensely. Although Malaysia perceives the Chinese officially as second class citizens, it does not ignore them. However, the situation in Turkey is quite the contrary. The Turkish Republic does not officially accept the existence of any ethnic group, and in the meantime of the Kurds, other than nonMuslims. Despite the fact that everyone is officially given the status of first class citizen, the Kurds perceive themselves in the disadvantageous and secondary position in practice and in various areas. On the other hand, establishment of an openly Kurdish party as it happens in Malaysia is a reason to be vetoed or closed down due to opposing the constitutional principle of "Turkey is an indivisible whole with its country and nation". Similarly, demanding autonomy also is perceived as separatism.

Table 14. Quantitative Scoring and Comparison in Terms of Political Organization and Political Rights

\begin{tabular}{lcc}
\hline $\begin{array}{l}\text { Country and } \\
\text { Ethnic Groups }\end{array}$ & $\begin{array}{l}\text { The Kurds } \\
\text { in Turkey }\end{array}$ & $\begin{array}{c}\text { The Chinese } \\
\text { in Malaysia }\end{array}$ \\
\hline Scoring & 5 & 2
\end{tabular}

In Turkey increasing the number of the municipalities by reforming the local governments in the recent years and strengthening the local governments even if it is through the increase of the number of metropolitan municipalities may be evaluated as a transition to an unnamed low level

Int'1 J. of Org. Bus. Excellence Vol. 2(1): 31 - 46 (2019) 
Alptekin, Musa Y.

decentralized administration. However, it is clear that a lot needs to be made in this regard.

\section{Armed Conflict/Terror}

It is clear that the most striking problem that the nation-states are confronted in managing the ethnic groups is the problem of armed conflict/terror. In terms of other 12 criteria, in the countries with insufficient policies and applications, the ethnic groups' taking the challenge of armed conflict is somewhat a common characteristic of those types of countries. It is known that in Malaysia such an ethnic armed conflict does not exist in terms of the Chinese. Investigating its reasons has a crucial significance and it will be partially attempted in the discussion section. In Turkey, the existence of an armed conflict around the Kurdish ethnic identity is a problem which is known by the whole world. Even though the ethnic armed resistance in Turkey may not be related to a single reason, it is mostly related to rejection and disapproval of the Kurdish identity by the state, and in this context there is no doubt that the problem has a political character. The right of basic education in the native language is the most concrete subject matter that comprises the political reason. However, the relational impact of other reasons is significant at least as much as this reason. And here, the most striking subject is economic welfare and level of social development.

Table 15. Quantitative Scoring and Comparison in Terms of Armed Conflict/Terrorism

\begin{tabular}{lcc}
\hline $\begin{array}{l}\text { Country and } \\
\text { Ethnic Groups }\end{array}$ & $\begin{array}{l}\text { The Kurds } \\
\text { in Turkey }\end{array}$ & $\begin{array}{l}\text { The Chinese } \\
\text { in Malaysia }\end{array}$ \\
\hline Scoring & 5 & 1 \\
\hline
\end{tabular}

The three most important reasons of why the Chinese do not resort to an ethnic and organized violence for their community rights are the recognition of the Chinese ethnic identity at the state level, economic satisfaction and level of social development. It would be very exceptional for an urban, rich and relatively prestigious ethnic group to resort to terrorism after being recognized in terms of ethnic identity. In Turkey, the situation is exactly the opposite. In Turkey, resorting to organized violence is a particular example of the widespread condition.

\section{RESULTS AND DISCUSSIONS}

Table 16. Cumulative Analysis of the Ethnic Problem in Turkey and Malaysia in terms of the 12 Criteria

\begin{tabular}{|c|c|c|c|}
\hline No. & Criteria of Analysis & Turkey & Malaysia \\
\hline 1 & $\begin{array}{l}\text { Historical Background and } \\
\text { Homeland }\end{array}$ & 4 & 2 \\
\hline 2 & Demographic Size (Ratio) & 3 & 4 \\
\hline 3 & $\begin{array}{l}\text { Regional Demographic } \\
\text { Intensity }\end{array}$ & 4 & 3 \\
\hline 4 & $\begin{array}{l}\text { Strategic Spread of } \\
\text { Population }\end{array}$ & 3 & 4 \\
\hline 5 & $\begin{array}{l}\text { International Spread of } \\
\text { Population }\end{array}$ & 4 & 2 \\
\hline 6 & Social Structure and Lifestyle & 4 & 2 \\
\hline 7 & $\begin{array}{l}\text { Intermarriages between } \\
\text { Ethnic Groups }\end{array}$ & 2 & 5 \\
\hline 8 & $\begin{array}{l}\text { Social Status and Socio- } \\
\text { Economic Developmental } \\
\text { Level }\end{array}$ & 3 & 1 \\
\hline 9 & $\begin{array}{l}\text { Religious Homogeneity and } \\
\text { Religious Rights }\end{array}$ & 2 & 4 \\
\hline 10 & $\begin{array}{l}\text { Linguistic Difference and } \\
\text { Native Language Right }\end{array}$ & 4 & 3 \\
\hline 11 & $\begin{array}{l}\text { Educational and Cultural } \\
\text { Level and Related Rights }\end{array}$ & 4 & 1 \\
\hline 12 & $\begin{array}{l}\text { Political Organization and } \\
\text { Political Rights }\end{array}$ & 5 & 2 \\
\hline 13 & Armed Conflict/Terror & 5 & 1 \\
\hline & Total & $47=4$ & $34=3$ \\
\hline
\end{tabular}

The comparison of the ethnic problems in Turkey and Malaysia in terms of the thirteen criteria is provided in Table-D. When the issue is evaluated in terms of thirteen criteria, it will be seen that Turkey is the most disadvantaged regarding two criteria. One of the two criteria is the matter of political organization and political rights and it shows that Turkey needs to make reforms in those matters. Other criterion is the matter of armed conflict and the actual situation that Turkey has been experiencing is already known. Although several ceasefire agreements have recently been made, no permanent results have been obtained. This shows that lacking a socioeconomic infrastructure the matter is coerced and it needs to be supported in terms of

Int'1 J. of Org. Bus. Excellence Vol. 2(1): 31 - 46 (2019) 
different criteria. The similar situation exists in Malaysia only in terms of one criterion. This is the matter of intermarriages between the ethnic groups and it would not be rational to expect improvements in this regard and to base the solution to the intermarriages due to a constant determinant regarding religion. Indeed, this matter alone would not cause an ethnic problem to become an unmanageable one. Despite this disadvantageous situation Malaysia might make the Chinese problem more manageable. In short, if different ethnic groups are in a more positive situation in terms of other 12 criteria they may live peacefully together without making intermarriages. As long as minimum improvements are provided in terms of other criteria, intermarriages between ethnic groups are not thought to be inevitable for ethnic harmony. On the other hand, Turkey is not in a good situation to be scored by 1 in terms of any criteria. However, Malaysia is scored by 1 in terms of three criteria. Those criteria are armed conflict, educational and cultural level and level of socio-economic development and social prestige. As none of those criteria are about constant and structural matters, it is understood that Turkey also needs to improve regarding those criteria. Lastly, when the sum of the scores of the criteria is taken into consideration, Turkey's total score is 43 and Malaysia's total score is 32 . With these scores, it is understood that while Turkey is located in the $4^{\text {th }}$ stage, Malaysia is located in the $3^{\text {rd }}$ stage. And this points out that as a nationstate, Turkey is relatively unsuccessful and in a disadvantageous position in the process of managing the Kurdish ethnic differences, and Malaysia is relatively more successful and is close to a manageable position in terms of the Chinese ethnic problem.

\section{CONCLUSIONS}

Although, Turkey and Malaysia are two very different countries in some respects, it is considered useful to compare two countries as they have many similarities in some other aspects. Primarily, Malaysia is a multi-religious society as opposed to Turkey. However, Turkey is almost completely a Muslim country. Similarly, the ratio of the ethnic groups in Malaysia is close to fifty percent. However, the only ethnic group whose population is more than 1 percent is the Kurds and their ratio in the country is below the ratio of the Chinese in Malaysia. On the other hand, the political systems of those two countries are different. While Malaysia is ruled by a mixed regime which is a mixture of parliamentarian democracy and monarchy, Turkey has been ruled by the parliamentarian system until the last year, and now it is ruled by a presidential system which is peculiar to Turkey.

At the same time, both countries have many commonalities. Both countries are known as Muslim countries and both are located on peninsulas having strategic significance on different corners of the Asian continent. Finally, both countries are intertwined by ethnic problems as nation-states. Thus, comparative analysis of Malaysia and Turkey in terms of ethnic problems and their solutions would be certainly useful. This comparison might help both countries to see their advantageous and disadvantageous situations and to develop policies over concrete examples where failures exist in this context. On the other hand, this comparison may be conducted between other nation-states experiencing ethnic problems around the world.

Consequently, the matters where Malaysia is the most disadvantageous in terms of the 13 criteria are the matters which are structural and hard to change such as marriages between ethnic groups, religious homogeneity and ratio and strategic spread of the population. However, the matters where Turkey is disadvantageous are not structural, indeed they are mostly political, and they have a higher possibility to change. Thus, Turkey might be in a more advantageous position than Malaysia in managing its ethnic problems if it makes an effort. In this regard, it appears that Turkey needs to get inspired from Malaysia's approaches which recognize ethnic identities and are structurally decentralized.

Int'1 J. of Org. Bus. Excellence Vol. 2(1): 31 - 46 (2019) 
Alptekin, Musa Y.

\section{REFERENCES}

Abdullah, A. \& Pedersen, P. B. (2009). Understanding Miltucultural Malaysia, Selangor: Prentice Hall.

Alptekin, M. Y. (2015). Küçük Asya: Malezya Tarih, Toplum, Kültür, Ekonomi ve Siyaset, [Little Asia: Malaysia, History, Society, Culture, Economy and Politics] Trabzon: Karadeniz Teknik Üniversitesi Yayınevi.

Comber, L. (1983). 13 May 1969 A Historical Survey of Sino-Malay Relations. Malaysia, Kuala Lumpur: Heinemann Asia.

Edmonds, J. (1968). Religion, Intermarriage and Assimilation: the Chinese in Malaya. Race, 10(1), 57-67.

Gullick, J. M. (1987). Malay society in the late nineteenth century: the beginning of change. New York: Oxford University Press

Gündüz-Hoşgör, A. \& Smits, J. (2002). Intermarriage between Turks and Kurds in Contemporary Turkey: Inter-ethnic Relations in an Urbanizing Environment, European Sociological Review, 18(4), 417432.

Hirchman, C. (1985). The Socaiety and Its Environment", in Frederica Bunge (Ed). Malaysia A Country Study, pp. 67-127, Washington DC: US Government Printing Office.

Jesudason, J. V. (1989). Ethnicity and the Economy. New York: Oxford University Press.

KONDA (2010). Toplumsal Yapı Araştırması Biz Kimiz [Social Structure Research Who We Are), Retrieved from www.konda.com.tr on 25 Januari 2019 (Open Access).

KONDA, (2006). Toplumsal Yapı Araştırması "Biz Kimiz?" [Social Structure Research, Who Are We?]. Retrieved from http://konda.com.tr/wpcontent/uploads/2 017/02/2006 09 KONDA Toplumsal Yapi. pdf on 28 January 2019. Open Access.

McDowall, D. (2004). Modern Kürt Tarihi [A Modern History of the Kurds], Translated by: Neşenur Domaniç. Istanbul: Doruk Publication.

Mohamad, M. (1981). The Malay Dilemma. Kuala Lumpur: Federal Publications.
Natali, D. (2009). Kürtler ve Devlet, [The Kurds and the State Evolving National Identity in Iraq, Turkey and Iran], Translated by: ibrahim Bingöl. İstanbul: Avesta Publication.

Rabushka, A. (1973). Race and Politics in Urban Malaya. Hoover California: Institution Press.

Sarıkaya, Y (2008). Tarihi ve Jeopolitik Boyutlarıla iran'da Milliyetçilik, [Nationalism in Iran with its Historical and Geopolitical Dimensions]. İstanbul: Ötüken Publications.

Sulochana, Nair (2007). "Fostering National Unity and Enhancing Ethnic Relations in Malaysi: The Role of Poverty Eradication Policies", in Abdul Rahman Embong (ed.), Rethinking Ethnicity \& Nation-Building, Selangor: Malaysian Social Science Association.

Yeğen, M., Uğraş U. T, \& Mehmet Ali, Ç. (2016). Kürtler Ne istiyor Kürdistan'da Etnik Kimlik, Dindarlık, Sınıf ve Seçimler, [What do the Kurds Want? Ethnic Identity, Religiosity, Class and Elections in Kurdistan]. İstanbul: İletişim Yayınları.

Young, K., Bussink, W. C. F., \& Hasan, P. (1980). Malaysia Growth and Equity in a Multicultural Societ., Baltimore: The John Hopkins University Press. 